\title{
A JUDICIALIZAÇÃO FOI TELEVISIONADA: a relação entre mídia e sistema judiciário
}

\author{
João Feres Júnior* \\ Patricia Bandeira de Melo** \\ Eduardo Barbabela***
}

\begin{abstract}
Em que medida o Sistema de Justiça exerce protagonismo no atual processo de conflito institucional do Brasil? A partir de uma análise crítica do conceito de Judicialização da Megapolítica, proposto por Ran Hirschl, discutimos o papel das instituições do Sistema de Justiça na atual crise política brasileira. Mostramos que Hirschl é impreciso acerca do problema da legitimidade no conflito entre poderes e omisso acerca da função que a grande mídia tem de deslocar a legitimidade dos poderes eleitos para as instituições do Sistema de Justiça. Para testar nossa hipótese, comparamos a evolução da aprovação popular dos poderes de Estado com a cobertura que os jornais Folha de S. Paulo, Estado de S. Paulo e o Globo, além do Jornal Nacional dedicaram a elas, de 2014 até 2018, usando os dados da pesquisa do Manchetômetro. Concluímos sugerindo aprimoramentos ao estudo da judicialização e particularmente ao conceito de judicialização da megapolítica.

Palavras-chave: Judicialização da política. Sistema de justiça. Mídia. Opinião pública. Ministério Público.
\end{abstract}

Estoura a pipoca. Tudo na quarta (13): Sergio Moro ouvirá Lula em Curitiba, o TRF em Porto Alegre analisará recurso de José Dirceu e o STF julgará o pedido de suspeição de Rodrigo Janot feito por Temer.

Folha de S. Paulo, Painel

\section{INTRODUÇÃO}

Não há como refletir sobre o atual processo de conflito institucional e crise da democracia brasileira sem falar no papel desempenhado pelo Sistema de Justiça, mais especificamente pelo Poder Judiciário e pelo Ministério Público (MP). O protagonismo dessas instituições é muito explícito e óbvio para ser ignorado, mesmo uma hipotética interpretação

* Universidade do Estado do Rio de Janeiro - UERJ. Instituto de Estudos Sociais e Políticos - IESP.

Rua da Matriz, 82. Botafogo. Cep: 22260-100. Rio de Janeiro - Rio de Janeiro - Brasil. jferes@iesp.uerj.br. ORCID: http://orcid.org/0000-0002-5830-0458

* * Fundação Joaquim Nabuco (Fundaj). Instituto Universitário de Lisboa (ISCTE-IUL).

Av. das Forcas Armadas, 1649-026. Lisboa - Portugal.

Gabinete ISCTE-IUL: 2W04E. patricia.bandeira.melo@ hotmail.com.

ORCID: http://orcid.org/0000-0003-4546-133X

*** Universidade do Estado do Rio de Janeiro - UERJ. Instituto de Estudos Sociais e Políticos - IESP.

Rua da Matriz, 82. Botafogo. Cep: 22260-100. Rio de Janeiro - Rio de Janeiro - Brasil. ebarbabela@gmail.com. ORCID: http://orcid.org/0000-0001-8058-7873 que relativize sua importância necessita fornecer razões bem fortes para fazê-lo.

De fato, esse protagonismo das instituições de justiça não é de hoje e nem é fenômeno exclusivo do Brasil, existindo inclusive em países com tradições consuetudinárias do direito. A tal fenômeno a literatura acadêmica atribuiu o nome de "judicialização da política”. Em outras palavras, para falarmos da crise atual brasileira é necessário que tratemos do tema da judicialização da política. Contudo, no presente artigo pretendemos ir um passo adiante e mostrar que no caso do Brasil essa judicialização se deu, em seu atual estágio, em combinação com o ativismo político da grande imprensa. O impeachment da presidente Dilma Rousseff, foi chamado por vários analistas da cena pública, de Golpe Jurídico-Midiático. A despeito da falta de profundidade analítica, da qual muitas dessas análises padecem, há algo de bastante verdadeiro, não propriamente no debate sobre a consistência conceitual do termo "Golpe", mas na identificação de uma sinergia ou aliança entre instituições de justiça e a grande imprensa. Pretendemos no texto que segue fornecer evidências que corroboram essa hipótese. 
Para cumprir nosso objetivo, faremos o seguinte percurso. Primeiro, examinaremos brevemente a literatura sobre judicialização da política, de sua origem até os dias de hoje, chamando atenção para algumas metamorfoses importantes identificadas por seus autores na maneira como as instituições jurídicas se relacionam com a democracia. Também discutiremos a literatura sobre a relação entre comunicação e o Judiciário, pois esse tema já foi objeto de investigação científica no Brasil e alhures. Em seguida, narraremos os principais fatos que levaram à atual crise institucional brasileira, chamando atenção para o papel da mídia e as percepções populares sobre as principais instituições democráticas. Por fim, analisaremos a cobertura que a grande mídia brasileira tem dedicado a essas instituições, identificando seu viés e a evolução temporal desde o começo de 2014 até 2018. Na conclusão, refletiremos sobre as possíveis soluções para a atual crise à luz dos problemas identificados ao longo do texto.

\section{JUDICIALIZAÇÃO DA POLÍTICA}

A preocupação em mostrar que o fenômeno da judicialização da política afetava tanto sistemas de direito consuetudinário como sistemas de direito romano já estava presente no livro que lançou essa expressão, editado จิ por Neal Tate e Torbjörn Vallinder, e intitulado N The Global Expansion of Judicial Power. Nessa

${ }^{1}$ No original: "1. the process by which courts and judges come to make or increasingly todominate the making of a fazer ou cada vez mais a dominar a construção de políticas públicas que haviam sido feito anteriormente (ou, acredita-se, devem ser feitas) por outras agências governamentais, especialmente os legislativos e executivos, e 2. o processo pelo qual negociações extrajudiciais e fóruns de decisão passam a ser dominados por regras e procedimentos quase judiciais (legalistas). ${ }^{1}$
Em menos de duas décadas a definição de Tate e Vallinder seria suplantada por interpretações mais complexas do fenômeno. $\mathrm{Na}$ verdade, tanto os processos de judicialização se intensificaram e se espalharam pelo mundo, quanto a bibliografia sobre o tema também cresceu de modo acelerado nesse período. Ran Hirschl (2008) acusa o termo "judicialização da política” de sofrer de falta de clareza analítica (analytical fuzziness) e propõe uma classificação dos trabalhos acadêmicos sobre o tema em quatro correntes: funcionalista, centrada em direitos, institucionalista e centrada nas cortes (Hirschl, 2008).

A vertente funcionalista, segundo Hirschl, vê a judicialização da política como consequência da complexificação das estruturas governamentais, que entre outras coisas deu origem a agências regulatórias e corpos administrativos semiautônomos (Hirschl, 2008). Autores com pendor mais sociológico atribuem o fenômeno ao crescimento da complexidade e contingência nas sociedades modernas (Luhmann, 1995) ou à expansão do Estado de Bem-Estar Social com seus múltiplos tentáculos regulatórios (Teubner, 1987; Habermas, 1988). Outros mais focados na economia o vêm como produto da necessidade de coordenação complexa de mercados convergentes no contexto da globalização (Stone-Sweet, 2000) ou da privatização e liberalização das atividades públicas, que requer ainda mais regulação (Vogel, 1998; Kelemen; Sibbitt, 2004). Seja qual for a razão última, a vertente funcionalista atribui o fenômeno a uma consequência praticamente inevitável do desenvolvimento social e institucional contemporâneo.

A corrente baseada em direitos nos é

bastante familiar. Ela vê a judicialização da política como um fenômeno altamente positivo de efetivação de direitos de baixo para public policies that had previously been made (or, itis widely believed, ought to be made) by other governmental agencies,especially legislatures and executives, and2. the procies, especially legislatures and executives, and2. the pro-
cess by which nonjudicial negotiating and decision-making forumscome to be dominated by quasi-judicial (legalistic) rules and procedures" (Tate; Vallinder, 1991, p. 28). Todas as traduções de trechos cujos originais foram publicados em língua estrangeira são de responsabilidade dos autores. 
cima. Em outras palavras, o Judiciário é ativado por movimentos sociais e grupos de interesse, como um canal mais confiável para se transformar políticas públicas do que outras burocracias estatais e, principalmente, do que o sistema político partidário. Aqui se encaixa a definição de Tate e Vallinder, mostrada acima. A carga normativa dessa visão está presente tanto naqueles que vêm o judiciário como um sistema íntegro e aberto frente à corrupção da política eleitoral (Scheingold, 1974) quanto naqueles que sublinham o suposto empoderamento que o fenômeno traz aos grupos historicamente oprimidos e sub-representados em uma sociedade (Epp, 1998).

A abordagem institucionalista entende a judicialização da política como um fenômeno produzido pela expansão da democracia mundo afora. Como a democracia representativa é um regime baseado na divisão de poderes e na constitucionalização de freios e contrapesos, sua instalação, segundo essa visão, requer a instituição de um Sistema de Justiça que funcione como árbitro apolítico dos conflitos gerados pelo funcionamento da política. Tal função é particularmente importante em arranjos institucionais federalistas (Shapiro, 1999).

Por fim, a vertente centrada nas cortes atribui aos juízes o papel de avançar sobre as prerrogativas de políticos eleitos, passando assim a exercer parte delas sem, ao mesmo tempo, ter a chancela do voto. Isto é, nessa abordagem fica mais clara a tensão entre os princípios do governo democrático e o instituto da revisão judicial constitucional. Alguns autores chegam a acusar juízes sequiosos de poder e cortes "imperialistas" de se envolver exageradamente em questões de cunho moral e em decisões políticas, excedendo-se assim os princípios da separação dos poderes e da governança democrática (Tushnet, 1999; Bork, 2002; Kramer, 2004; Waldron, 2006).

A despeito do papel central que o caso norte-americano ocupa em quase toda essa bibliografia, é impossível não notar que a literatura nacional sobre o tema da judicialização também se encaixa bastante bem nessas divisões. Só para citar alguns exemplos mais proeminentes, o elogio entusiasmado da judicialização "republicana" e de "baixo para cima" feito por Luiz Werneck Vianna (1999) e seguidores, pertence claramente à segunda vertente identificada por Hirschl, a judicialização baseada em direitos. Muito bem recebida nas primeiras décadas da Nova República, enquanto a luta por efetivação dos direitos estabelecidos pela Constituição de 1988 era intensa, tal interpretação começou a mostrar suas fragilidades analíticas frente aos novos acontecimentos da cena política a partir da eleição de Lula para a Presidência da República, e particularmente com o advento da Ação Penal 470 e, posteriormente, da Operação Lava Jato.

A leitura de Werneck Vianna também não é destituída de elementos sociológicos funcionalistas (primeira vertente), que entendem a judicialização como uma consequência da complexificação das sociedades modernas. Tal visão está presente também no trabalho de Leonardo Avritzer e Marjorie Marona sobre o tema (Avritzer; Marona, 2014), segundo o qual o processo da judicialização da política no Brasil seria soberano e deliberativo, pois, o instituto da emenda constitucional permitiria a revisão e adaptação constante da Constituição por meio da deliberação de um parlamento, o poder soberano, aberto a demandas advindas da sociedade civil (Avritzer; Marona, 2014).

Há outros exemplos de adequação do esquema analítico proposto por Hirschl para a academia nacional. O protagonismo do Ministério Público é identificado por Rogério Arantes com argumentos bastante próximos à quarta vertente, a do ativismo das cortes (Arantes, 1997). Já a contribuição de Ernani Carvalho é claramente institucionalista, com uma leitura fortemente focada no controle abstrato de constitucionalidade e na ação racional dos agentes que ativam o Supremo Tribunal Federal (STF) (Carvalho, 2009). Outra abordagem institucionalista é a que Fabio Kerche utiliza em sua análise do Ministério Público, atribuin- 
do profeticamente os problemas que a falta de accountability e de estrutura hierárquica em seu desenho institucional trazem para o funcionamento da democracia (Kerche, 2009).

Não é nosso objetivo no presente artigo fazer uma revisão exaustiva da literatura nacional sobre a judicialização, mas sim apontar para outro elemento da contribuição de Hirschl. Segundo esse autor, todas essas vertentes interpretativas não levam a sério o caráter político das cortes, isto é, não as consideram como instituições políticas. Há, contudo, uma quinta vertente interpretativa que cobriria essa lacuna (Gillman, 2002; Ginsburg, 2003; Lovell, 2003; Hirschl, 2004; Graber, 2006; Whittington, 2007; Hirschl, 2008). Nela temos a inversão total da segunda vertente, de efetivação de direitos de baixo para cima, pois, a judicialização agora é vista como "de cima para baixo", servindo a interesses estratégicos das forças políticas em competição. É o cálculo político que guia tanto o comportamento dos juízes quanto o dos políticos frente às instituições do Sistema de Justiça. Hirschl (2008) batiza o fenômeno assim descrito de judicialização da megapolítica ${ }^{2}$ ou, em outros termos, da política pura. Na verdade, a despeito de não estar explicitado pelo autor, o que temos é mais uma politização do Sistema de Justiça, no qual juízes e procuradores passam a agir como agentes políticos, às vezes publicamente, identificados com posições políticas ou partidos.

Hirschl de fato vê a evolução da judiฟิ cialização em três etapas. Primeiro, temos as ป cortes agindo para garantir o cumprimento do s. procedimento legal (due process), direitos civis e liberdades básicas, um processo em perจิ pétua expansão que alguns autores chamaram $\dot{2}$ de juridificação das relações sociais. Segundo, $\underset{\infty}{\infty}$ os tribunais passam a incidir sobre o direito $\Rightarrow$ administrativo e sobre as políticas públicas. E, por fim, temos a judicialização da megapolítica (Hirschl, 2008). A despeito da dificuldade reconhecida pelo autor de estabelecer claramente uma separação entre o que é ou não

${ }^{2}$ Para um excelente estudo sobre o tema produzido no Brasil ver Fernandes (2017). político nos dias de hoje, ele enumera uma ampla gama de temas inegavelmente políticos, no sentido mais imediato do termo, aquele que diz respeito à política institucional/eleitoral. São eles: a legitimidade do sistema político, resultados eleitorais, desqualificação de políticos e de partidos políticos, aspectos relativos à identidade nacional, crimes e genocídios de responsabilidade nacional. A judicialização da megapolítica também abarca o avanço do judiciário sobre prerrogativas tipicamente atribuídas ao executivo, como política fiscal, política externa e segurança nacional, estendendo inclusive a um tema central da política que é a decisão sobre mudanças de regime. Por fim, o autor também inclui nesse fenômeno o poder adquirido por cortes internacionais e altas cortes nacionais de adjudicar casos de reparação contra minorias (Hirschl, 2008).

Para entender completamente o argumento deste autor, é preciso primeiro encará-lo no seu aspecto mais geral que é o de mostrar, contra a literatura de direito constitucional, que a judicialização da megapolítica não pode ser entendida pela mera interpretação das constituições e das dinâmicas de sua efetivação institucional. O fenômeno é político, porque os atores políticos passam a contar com as cortes como um instrumento de ação e, também, porque as decisões das cortes incidem diretamente sobre assuntos antes limitados às instituições com conexão direta com a política eleitoral: Legislativo e Executivo. Para além desse ponto mais geral, a clareza esquemática do argumento do autor faz com que ele se preste bem à função de ferramenta analítica para compreender o caso brasileiro, ao tempo em que o exame do caso brasileiro nos ajuda a identificar fragilidades no próprio esquema proposto pelo autor. Queremos apontar aqui duas dessas fragilidades: a sucessão de etapas da judicialização e a natureza política da terceira etapa.

A literatura nacional sobre o tema da judicialização da política parece seguir as etapas propostas por Hirschl (2008) em ordem cronológica. Contudo, a ordem dos fatos não 
foi a mesma, pois é possível argumentar que a Constituição de 1988 inaugurou a um só tempo todas as três formas: expansão do sistema de direitos e liberdades básicas, regulação de políticas públicas e judicialização da megapolítica. Olhando retrospectivamente para os fatos detectamos a presença precoce de judicialização da megapolítica, como na definição das regras eleitorais (e não somente o controle do cumprimento procedimental da legislação), que tem sido prerrogativa das supremas cortes brasileiras ao longo de toda a Nova República. Outro exemplo marcante que se encaixa bastante bem na tipologia do autor canadense foi o impeachment do ex-presidente Fernando Collor.

Na verdade, a Constituição contém os pré-requisitos para o desenvolvimento dos três tipos de judicialização. E de fato, ainda que estivessem presentes desde o início do período sob a nova Carta, o desenvolvimento institucional dessas práticas foi desigual ao longo do tempo. É inegável que nos últimos anos a judicialização da megapolítica brasileira assumiu a dianteira, com o Supremo Tribunal Federal destituindo deputados e até presidentes de casas legislativas, presidindo outro processo de impeachment, cancelando o direito da presidente de nomear um ministro, cancelando o direito político de um cidadão, Lula, ser nomeado ministro, etc.

É na questão da natureza política da terceira etapa, ou seja, da judicialização da megapolítica, que a teoria de Hirschl se torna um pouco incerta quando aplicada ao caso brasileiro. A tese geral parece bastante correta, a judicialização da megapolítica prospera quando o sistema político entra em crise, ou como declara o autor, quando fica "travado" ou "disfuncional” (Hirschl, 2008). Mas quando entramos nos detalhes dos exemplos dados pelo referido autor, vemos que ele tem em mente a manipulação do sistema político pelas forças da situação usando como instrumento as cortes, ou casos em que os políticos no poder transferem para as cortes decisões potencialmente impopulares ou ainda quando a oposição usa a litigância para aumentar sua exposi- ção pública, a despeito do resultado concreto. Na verdade, em grande medida, o autor vê as cortes como uma força conservadora que políticos no poder usam com o intuito de manter o status quo. Mesmo quando trata do problema da sucessão de partidos no poder, o raciocínio é o seguinte: quando o partido tem alta probabilidade de se manter no poder, a ativação das cortes é baixa, mas quando pressente a perda do poder, ele usa as cortes para garantir que o partido que o suceda tenha seu raio de ação diminuído (Hirschl, 2008).

Resumindo, para ele a judicialização da megapolítica se explica acima de tudo pelo fato de as cortes serem capazes de prover maior legitimidade para decisões que, se deixadas no terreno contencioso da política institucional, continuariam a gerar conflito e perdas para o grupo no poder. "Legitimidade" aqui é a palavra-chave. Como escrevem Gibson; Caldeira e Spence (2003) em seu estudo sobre as decisões da Suprema Corte acerca da eleição presidencial de 2000 nos Estados Unidos:

\footnotetext{
a exposição a tribunais - incluindo a exposição associada a circunstâncias controversas - aumenta mais do que prejudica a legitimidade do judiciário, mesmo quando a opinião pública rejeita a decisão do Tribunal. Quando os tribunais se tornam salientes, as pessoas ficam expostas às armadilhas simbólicas do poder judicial - "o templo de mármore, o banco alto, a cortina roxa, as vestes negras” (Gibson; Caldeira; Spence, 2003, p. 553). ${ }^{3}$
}

Mas como os atores políticos avaliam a legitimidade de uma decisão? Hirschl (2008) não se preocupa em responder essa questão que é fundamental para seu esquema explicativo. Ora, em democracias representativas, o apoio popular a tal ou qual plataforma política se manifesta periodicamente por meio de

${ }^{3}$ No original: exposure to courts - including exposure associated with controversial circumstances - enhances rather than detracts from judicial legitimacy, even among those who are disgusted with the Court's ruling. When courts become salient, people become exposed to the symbolic trappings of judicial power - 'the marble temple, the high bench, the purple curtain, the black robes'.40 When the news media covered the Court's deliberations surrounding the election, it generally did so with the greatest deference and respect (Gibson; Caldeira; Spence, 2003, p. 553. Tradução nossa). 
eleições. Mas fora dos períodos eleitorais, que corresponde à maioria do tempo, como se mede a legitimidade das instituições? Uma resposta mais imediata seria por meio da opinião pública. Contudo, tal resposta nos faz avançar ainda mais em terreno conceitual pantanoso, pois se a legitimidade já é algo difícil de se medir, fora de situações pontuais como eleições, a opinião pública é objeto ainda mais fugidio. Claro, há os surveys, mas tais ferramentas possuem limitações, pois têm periodicidade incerta, são conduzidos por diferentes organizações com interesses distintos na cena política e são por demais acadêmicas para o consumo da comunicação de massas, a despeito de serem hoje em dia bastante usados. Surveys de opinião pública não são as únicas nem as principais balizas utilizadas pelos agentes políticos para auferir a legitimidade das instituições frente à opinião pública, pois no dia-a-dia a principal fonte de opinião para os agentes é a grande mídia. Ainda segundo Gibson; Caldeira e Spence "Quando os meios de comunicação cobriram as deliberações da Corte em torno da eleição, geralmente o fizeram com a maior deferência e respeito" (Gibson; Caldeira; Spence, 2003, p. 553). ${ }^{4}$

Mesmo que nos dias de hoje seja indubitável o avanço da internet e das redes sociais, a grande mídia tradicional é a responsável quase que exclusiva pela produção de conteúdo jornalístico. Muito desse conteúdo é veiculado pelos portais noticiosos das grandes empresas จิ de comunicação, como UOL, G1, R7, etc., sei não por canais tradicionais como jornais, re¿े vistas e televisão. Incapazes de competir na \& produção de notícias, por não terem recursos จิ financeiros suficientes para bancar repórteres $\dot{\sim}$ e jornalistas, os blogs e sites alternativos se ले conformam na maioria das vezes em comentar

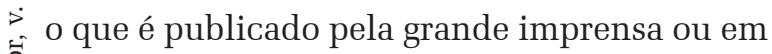
realizar produções independentes que, para serem menos onerosas, levam mais tempo para serem executadas e veiculadas.

${ }^{4}$ No original: When the news media covered the Court's deliberations surrounding the election, it generally did so with the greatest deference and respect (Gibson; Caldeira; Spence, 2003, p. 553).
Diferentemente dos surveys, consideradas como ferramentas mormente passivas de medida da opinião pública, a grande mídia não só reporta a opinião corrente, ela a forma ativamente, em larga medida se utilizando de estratégias de agendamento - escolha dos temas noticiados ${ }^{5}$ - e enquadramento - interpretação dada a cada tema noticiado. ${ }^{6}$ Em países nos quais os sistemas de comunicação de massas são plurais e sujeitos à regulação pública, temos maior abertura a várias perspectivas políticas e sociais, e a mídia se aproxima do sentido etimológico da palavra, ou seja, é um meio usado pelas agentes políticos para amplificar e estruturar o debate público e a formação da opinião (Sodré, 1999; Lima, 2001; Downing, 2002; Brittos; Bolaño, 2005).

O papel da imprensa nas distintas democracias da atualidade não é simples de se compreender, transitando entre ser protagonista do debate público e mediá-lo com voz e visibilidade. O jornalismo executa um papel essencial como instituição social que não só produz narrativas, mas constrói procedimentos que permitem entender como esse mundo narrado foi pensado. Somado a isso, sua capacidade de hierarquizar acontecimentos e assuntos alude à capacidade da mídia em influenciar a opinião pública (Becker et al., 2017).

Conforme Becker et al. (2017) apontam, historicamente os meios de comunicação têm o papel de influenciar ações e crenças, tornando-se detentores do papel de socialização e de mediação política ante a baixa credibilidade dos partidos políticos. A importância dos meios

${ }^{5}$ De acordo com a teoria do agenda-setting (Mccombs; Shaw, 2000; Mccombs, 2005), apresentada pela primeira vez pelos autores em 1972, a mídia define sua pauta a partir de eventos raros narrados como se fossem episódios comuns. A teoria do agendamento busca elucidar os efeitos resultantes da abordagem de determinados temas por parte dos meios de comunicação sobre a agenda de preocupações dos indivíduos comuns.

${ }^{6}$ Os enquadramentos reúnem esquemas de apresentação, de seleção, de ênfase e exclusão que indicam possibilidades de interpretação da notícia. O conceito emerge algumas vezes interrelacionado ao paradigma do agendamento, quando os teóricos do agenda-setting enfatizam que a mídia não apenas determina sobre o que os indivíduos devem pensar, mas também como devem pensar acerca dos assuntos agendados (Mccombs, 2009). 
na sociedade está em alimentarem tanto as informações como os discursos que circulam na mesma, além de favorecer a criação de novos espaços para os sujeitos produzirem "sentido de si mesmos, da relação com outros, o que frequentemente se entrelaça com as instituições e os padrões culturais arraigados" (Maia, 2012, p. 209). Como a própria autora afirma, os jornais possuem o potencial para transformar as relações do cotidiano, dramatizando conflitos, relacionando-os a valores e, principalmente, politizando as experiências vividas.

O jornalismo brasileiro contemporâneo cultiva a autoimagem de profissionalismo, imparcialidade, equilíbrio e isenção (Corrêa, 2002 apud Biroli; Miguel, 2017). Contudo, como asseveram Biroli e Miguel, os meios de comunicação são uma esfera na qual a representação de interesses específicos, a mediação de relações entre instituições e cidadãos e a imposição de visões de mundo constituem um modo de atuação política e proporcionam a reprodução de valores socialmente hegemônicos e o consequente silenciamento do conflito (Biroli; Miguel, 2017).

Em estudos da área da comunicação, contudo, outra visão começou a surgir, apropriando-se da ideia de partidos catch all, originária da Ciência Política, para definir a compreensão de partidos que buscam abranger em seu interior o mais amplo espectro ideológico possível para maximizar coalizações e, consequentemente, votos. No jornalismo, a lógica de catch all também se aplicaria para definir jornais com posicionamento ideologicamente neutro com o fito de maximizar a audiência.

Os grandes periódicos no Brasil dizem adotar um modelo de jornalismo similar ao norte americano, que seria "independente", com matérias informativas e pouco espaço para interpretação. As opiniões ficariam restritas a colunas, artigos de opinião assinados e editoriais (Rizzoto; Prudencio; Sampaio, 2017). No entanto, esse posicionamento neutro não mais é vantajoso para os veículos, pois esses são estimulados a ter posicionamento ativo para garantir sua sobrevivência em um mercado cada vez mais fragmentado e competitivo, além de terem de responder a hábitos de consumo novos que surgem, principalmente entre os mais jovens (Lycarião; Carvalho; Albuquerque, 2018).

Se nos Estados Unidos essa tomada de posição é uma realidade, no Brasil ainda estaríamos avançando lentamente, influenciados pelas novas mídias que surgem no país. Com a emergência da internet, a concepção de um sistema plural de comunicação ganhou popularidade, principalmente, com a transformação do público que, ao longo do processo de transformação dos meios, se segmentou e especializou suas demandas por informação. Apesar dessa pluralidade, o jornalismo tradicional ainda mantém seu papel como gate keeper, centralizando a produção de conteúdo para um público cada vez mais volumoso (Santos; Albuquerque, 2019). A conformação da imprensa brasileira é bastante diversa da norte-americana. Aqui comunicação de massas é dominada por um oligopólio composto por um reduzido número de grandes empresas privadas familiares. Em contextos como o brasileiro, a mídia não pode ser tratada apenas como meio, mas também como agente político. O histórico de militância política e de manipulações da cobertura feitas pelos grandes veículos de comunicação nacional é longa e fartamente estudada e documentada pela literatura acadêmica. Como resultado, a adesão da imprensa brasileira à democracia foi por vezes bastante problemática, e isso se deve a aspectos como a concentração de meios de comunicação nas mãos de poucos grupos e a regulação deficiente da comunicação em nosso país (Albuquerque, 2018). ${ }^{7}$ Em suma, retomando a discussão com Hirschl, se a judicialização da megapolítica depende diretamente da conjuntura, essa, por seu turno, é

${ }^{7}$ A regulação pública da comunicação no Brasil é bastante limitada. A Constituição Federal em seu artigo $54^{\circ}$ inciso I proíbe que deputados e senadores celebrem contratos com empresa concessionária de serviço público. Além disso o inciso II veda a congressistas serem proprietários de empresas que recebam benefícios da União (Brasil,1988). Contudo, mesmo essas parcas leis não são cumpridas. 
altamente dependente do clima de opinião pública que é em grande medida produzido pela mídia. Isso é particularmente verdadeiro em períodos não eleitorais. Particularmente em casos como o Brasil, a mídia age politicamente construindo ou desconstruindo a legitimidade das instituições democráticas.

Nos últimos anos, os grandes meios têm destacado cada vez mais as ações do Sistema de Justiça usando a bandeira do combate à corrupção como ação política para deslegitimar governos. Ou, vista a questão por outro lado, para que a judicialização da megapolítica se dê, é necessário que seja conferido às ações de juízes e promotores um alto grau de legitimidade. Os poderes do Sistema de Justiça, Judiciário e Ministério Público, são na prática dependentes da mídia para angariar legitimidade, particularmente quando se insurgem contra os poderes eleitos, Legislativo e Executivo. Uma decisão de juiz de primeira instância que não é seguida por cobertura midiática bombástica, pode ser mais facilmente revertida nas instâncias superiores. A acusação feita por um procurador da República que não é alardeada pela mídia pode mais facilmente ser rejeitada por um juiz.

Para corroborar o papel crucial da opinião pública na deslegitimação do sistema político e, assim, no sucesso da judicialização da megapolítica, tomemos o exemplo dado pelo próprio juiz Sergio Moro, provavelmente, o personagem mais saliente da atual fase จิ da judicialização da política em nosso país, o ปิ qual em texto publicado em 2004 reflete so¿े bre a Operação Mani Pulite (mãos limpas) na ¿ Itália. O juiz de Maringá é bastante direto: "O จิ processo de deslegitimação foi essencial para \&. a própria continuidade da operação Mani Puliஓ te" (Moro, 2004, p.57). Em seguida, Moro cita $\vec{*}$ várias tentativas do Executivo e Legislativo italianos para estancar a Operação, as quais foram frustradas pela "reação negativa da opinião pública” (Moro, 2004, p.57), entre elas um decreto legislativo exarado pelo primeiro-ministro Silvio Berlusconi, enfrentado pelos procuradores da Mani Pulite com uma ameaça de demissão geral que causou grande reação popular - qualquer semelhança com a ameaça pública ao Congresso Nacional feita pelos procuradores da Lava-Jato quando da votação do projeto de lei contra o abuso de autoridade não é mera coincidência. À época, os procuradores apelidaram a emenda de "Lei da Intimidação".

Moro é taxativo: "Um Judiciário independente, tanto de pressões externas como internas, é condição necessária para suportar ações judiciais da espécie. Entretanto, a opinião pública, como ilustra o exemplo italiano, é também essencial para o êxito da ação judicial” (Moro, 2004, p.57). Ele também deixa claro o papel fundamental que a mídia tem para esse fim:

os responsáveis pela operação ManiPulite ainda fizeram largo uso da imprensa.... a investigação da 'ManiPulite vazava como uma peneira”. Tão logo alguém era preso, detalhes de sua confissão eram veiculados no 'L'Expresso', no 'La Republica' e outros jornais e revistas simpatizantes (Moro, 2004, p. 59).

Talvez por soberba, arrogância, ou falta de rigor analítico, o magistrado dá mais agência aos "giudiciragazzini” italianos do que à imprensa propriamente dita, mas é notável nessa passagem o uso do adjetivo "simpatizantes", pois ele denota consciência de que a imprensa deve ser tomada como aliado político. Aqui abre-se para nossa observação um fenômeno não capturado pela análise de Hirschl (2008), o judiciário politizado, ou ativista, da judicialização da megapolítica existente no caso brasileiro, e provavelmente, também no italiano, em íntima colaboração com uma mídia altamente politizada. Tal hipótese pode ser testada por meio da análise de outros casos, o que infelizmente não podemos fazer no presente artigo. Trataria de tentarmos estabelecer, comparativamente, as configurações dos sistemas midiáticos em casos de judicialização da megapolítica e sua colaboração com o Sistema de Justiça.

\footnotetext{
${ }^{8}$ ALESSI, Gil. "Procuradores da Lava Jato ameaçam renunciar se Congresso aprovar "lei da intimidação”". El País, 30 de novembro de 2016. Disponível em: https://brasil.elpais.com/brasil/2016/11/30/politica/1480515868_829483. html. Acesso em 13 de setembro de 2017
} 
O importante para os objetivos desse ensaio neste momento, contudo, é notar a dependência que o Sistema de Justiça tem da mídia e, mais especificamente, a sinergia entre a politização da justiça e a politização da mídia. Na prática temos duas distorções ameaçadoras para a democracia, ou seja, a captura desses dois sistemas de controle social e político, mídia e justiça, por interesses políticos. O fato de que a judicialização da megapolítica constitui uma tal ameaça está presente no ensaio de Hirschl (2008) e de tantos outros autores. Já a politização da mídia é problema tratado em uma vasta literatura internacional e brasileira (Entman, 1993; Miguel, 1999; Colling, 2004; Gentzkow, 2006 ; Della Vigna, 2007; Lima; Aldé, 2007). O que vem ganhando cada vez mais espaço na literatura brasileira é a combinação desses dois fenômenos.

A relação entre comunicação e Judiciário é antiga, apesar de nos últimos anos notarmos um aumento da cobertura especializada no Judiciário e, a partir dos anos 2000, um grande investimento do Judiciário em comunicação, com a TV Justiça sendo o melhor exemplo desse processo de divulgação de ações do Sistema de Justiça (Albuquerque, 2017). Foi a partir dos anos 1990 que o Judiciário começou a ganhar algum destaque midiático, em conjunto com o crescimento do interesse pelos demais poderes (Executivo e Legislativo). A Comissão Parlamentar de Inquérito (CPI) de 1999 foi essencial para chamar a atenção para temas como o controle e o papel do Judiciário e apontar para a importância de uma Reforma Judiciária (Albuquerque, G, 2017). Uma das táticas do então governante para pautar a reforma foi mobilizar a opinião pública e garantir um ambiente favorável a mudanças estruturais no Judiciário (Albuquerque, A, 2018). Mais especificamente o governo Lula utilizou-se de divulgação de dados técnicos sobre o Poder Judiciário e também de falas do então presidente nas quais comparava o Poder Judiciário a uma caixa preta, para garantir visibilidade ao tema na mídia, além de apoio popular. A criação do
Conselho Nacional de Justiça também foi um reflexo de tentativas de institucionalização de controle externo ao Judiciário.

Ainda sob o governo do Partido dos Trabalhadores o processo de judicialização da política começou a se acelerar, primeiro com o chamado Escândalo do Mensalão, que já apresentava características similares de colaboração entre judiciário e mídia, e que mais tarde viriam a se consolidar e se radicalizar na Operação Lava Jato. A associação de governos do PT à corrupção na tentativa deslegitimação desses mesmos governos favoreceu a legitimação da intervenção do Judiciário na política, que, por seu turno, depende da ampla publicização dos atos judiciários feita pela mídia (Albuquerque, A, 2018).

Nas seções seguintes tentaremos mostrar como tal combinação entre judicialização da política e politização da imprensa se deu no Brasil, particularmente no período mais recente de nossa vida democrática, a partir da subida da esquerda ao poder, representada pelo Partido dos Trabalhadores (PT), e particularmente da segunda vitória eleitoral de Dilma Rousseff, quando se instaurou no país uma grave crise política que se arrasta até os dias de hoje.

\section{METODOLOGIA}

A metodologia utilizada neste trabalho consiste na análise de textos jornalísticos publicados de janeiro de 2014 a dezembro de 2018, com vistas a compreender como a mídia brasileira noticiou as principais instituições democráticas do país nesse período. Para tanto, recorremos aos dados do Manchetômetro (www.manchetometro.com.br), website de acompanhamento da cobertura midiática sobre temas de política e economia. ${ }^{9}$ Esse rastre-

${ }^{9}$ O Manchetômetro é um site de acompanhamento da cobertura da grande mídia acerca de temas relacionados à economia e à política, produzido pelo Laboratório de Estudos de Mídia e Esfera Pública (LEMEP). O LEMEP tem registro no Diretório de Grupos de Pesquisa do CNPq e é sediado no Instituto de Estudos Sociais e Políticos (IESP) da Universidade do Estado do Rio de Janeiro (UERJ). 
amento consiste em avaliar manchetes e chamadas de capa, editoriais e páginas de opinião dos jornais impressos Estado de S.Paulo, Folha de S.Paulo, O Globo, além do noticiário do Jornal Nacional, da Rede Globo.

Aplicamos a metodologia de análise de valências (MAV), que é padrão utilizado internacionalmente para auferir algum viés dos meios de comunicação (Feres Junior, 2016). Ademais, a MAV é metodologia bastante adequada para a análise quantitativa de textos altamente politizados, ao avaliar seu sentido em relação ao objeto estudado (idem, p. 293). A análise de valências integra a tradição dos estudos de mídia e foi empregada de modo pioneiro no Brasil por Marcus Figueiredo, professor e pesquisador do antigo Instituto Universitário de Pesquisas do Rio de Janeiro (IUPERJ), atual Instituto de Estudos Sociais e Políticos (IESP-UERJ), e seus discípulos (Aldé, 2003; Aldé; Mendes; Figueiredo,2007; Hopkins; King, 2010; Mundim, 2012; King; Pan; Roberts, 2013; Mundim, 2014; Borba; Veiga; Martins, 2015). Esse modelo analítico busca responder à seguinte questão: qual a posição que o texto apreciado expõe quanto aos tópicos mencionados?

Ao longo do período de levantamento dos dados, realizamos uma análise de valências, assim definida: (a) positivas - são as notícias que contêm referências predominantemente favoráveis ao tópico em questão, sejam elas factuais ou normativas; (b) negativas - são aquelas que จิ contêm indícios predominantemente contrários กิ ao personagem ou tema em questão; (c) neutras ¿े - quando o texto é particularmente descritivo e ¿ destituído de conteúdo claramente positivo ou จิ negativo, ele recebe a classificação de neutro; $\dot{\sim}$ (d) ambivalentes - quando há equilíbrio entre ळ referências negativas e positivas, a notícia é

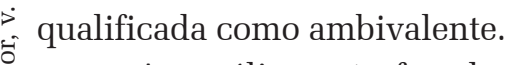
base nas seguintes justificativas:

a) a capa de um jornal tem poder comunicativo muito maior do que as notícias de seu miolo. A manchete, as chamadas e as fotos da capa são os elementos comunicativos mais vistos na publicação, seja pelos assinantes e seus familiares, pelas pessoas que compram os jornais nas bancas ou mesmo pelas pessoas que circulam todos os dias em frente às bancas de revistas, onde as capas dos periódicos são expostas para a apreciação pública. Há, inclusive, noticiários televisivos e radiofônicos em que são lidas todas as manhãs as manchetes dos principais jornais do país, sem detalhamento do seu conteúdo;

(b) as manchetes e chamadas de primeira página são aquelas agendadas pelos editores do jornal como as que melhor resumem o conteúdo de toda a publicação, as que são tratadas como de maior interesse dos leitores. A capa funciona como um índice, um guia para leitura.

No caso das páginas de opinião, elas contêm três gêneros de textos jornalísticos: editoriais, artigos de opinião e colunas. Os editoriais trazem a opinião dos donos e dos editores dos veículos, responsáveis por tomar as decisões sobre quais temas serão cobertos e como eles serão abordados, seja em reportagens ou em outros artigos de opinião. Os colunistas, por sua vez, são profissionais de diversas áreas que escrevem periodicamente em colunas específicas e regulares dos jornais. Sua presença reflete ou tenta refletir muitas vezes uma pluralidade de perspectivas ou reforçar posicionamentos específicos. Por fim, os artigos de opinião são textos feitos por articulistas convidados que escrevem sobre temas específicos e não mantém vínculo trabalhista com o periódico.

No caso do Jornal Nacional, a análise leva em consideração todo o conteúdo veiculado diariamente pelo telejornal, dentro dos temas de economia e política. Além da codificação de valências, os tempos das notícias são computados, o que nos permite mapear a exposição temporal de cada assunto, personagem, partido ou assunto polêmico em comparação à totalidade do noticiário.

Como as manchetes e títulos de capa são mensagens abreviadas, que resumem o sentido do fato noticiado, frequentemente utilizamos o 
texto de abertura da notícia, abaixo do título, representativas de toda a população brasileira, para determinar a valência. No caso dos arti- por meio de técnicas de amostragem, é razoágos de opinião, editoriais e textos mais longos vel supor que representam pelo menos em parna capa, a valência é atribuída a partir de um te a opinião pública acerca das instituições. A julgamento acerca de todo o conteúdo da ma- figura acima deve ser analisada com cuidado, téria, pensando as referências nela contidas. dos detalhes mais gerais aos mais específicos. Já no telejornal, todo o conteúdo da notícia é considerado na qualificação da valência. As análises são computadas separadamente para cada ator presente no texto. Por exemplo, se há uma chamada "Partido da presidente Dilma é denunciado em esquema de corrupção”, há dois atores neste texto, que são codificados separadamente: Dilma Rousseff e o Partido dos Trabalhadores (PT). Assim, é possível que em um mesmo texto exista mais de uma codificação de atores distintos, o que possibilita que a soma total de Gráfico 1 - Confiança nas instituições no Brasil

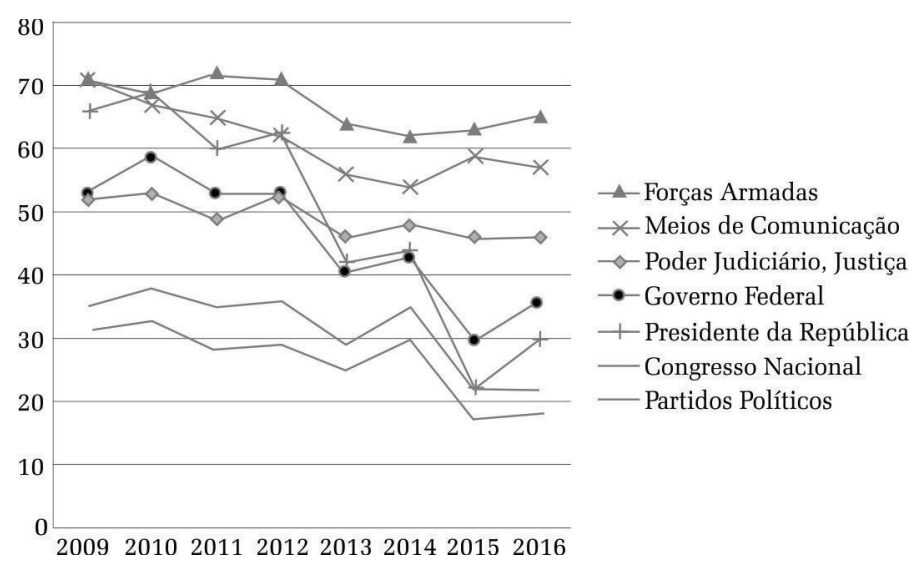
Fonte: IBOPE Inteligência aparições de instituições seja superior ao número de textos analisados ${ }^{10}$.

\section{COMPARANDO A COBERTURA JORNALÍSTICA DOS PODERES}

A nossa hipótese central nesse artigo é de que há uma correlação positiva entre a desconstrução dos poderes políticos eleitorais por parte da mídia e a queda da sua aprovação pela opinião pública, que é paralela a uma correlação positiva entre a ascensão da noticiabilidade (cobertura jornalística) dos poderes não eleitos (Judiciário e Ministério Público) e a manutenção de sua aprovação pública, a despeito da queda quase generalizada da aprovação popular das instituições, conforme o gráfico a seguir.

Como as pesquisas de opinião cujos resultados estão expressos no gráfico acima são

${ }^{10}$ As notícias são classificadas por um membro da equipe do Manchetômetro e posteriormente revisadas por um segundo membro. Em caso de discordância sobre a valência atribuída, um terceiro membro é consultado e seu veredicto funciona como critério de desempate. A equipe é instruída a fazer classificações conservadoras - ou seja, apenas identificar valências positivas ou negativas nos casos em que a inclinação discursiva for clara e intensa.

De início, podemos notar que todas as instituições enumeradas sofreram queda de aprovação popular durante o período que vai de 2009 a 2015, ou seja, do último ano do governo Lula ao primeiro ano do segundo governo Dilma. Dito isso, é possível também identificar três grupos de instituições e um outlier (valor atípico). Temos as Forças Armadas e os meios de comunicação que iniciam a série com as porcentagens de aprovação mais altas, em torno de $70 \%$, e sofrem pouca variação, terminando em torno de $60 \%$. Temos o Congresso Nacional e os Partidos Políticos que começam a série com as marcas mais baixas, entre $30 \%$ e $35 \%$, e terminam em torno de $20 \%$, com um comportamento de decréscimo praticamente paralelo de queda em torno de $15 \%$ - algo que era de se esperar dado a dependência entre tais variáveis. Há o grupo formado pelo Poder Judiciário e o Governo Federal que começa com escores médios, um pouco acima de 50\%, e tem um comportamento de queda bastante similar, até o ano de 2014. A pesquisa de 2015 registra um resultado bastante diferente, com o Governo Federal despencando para 30\%, e o Judiciário 
marcando $46 \%$, ou seja, no período enquanto o Governo Federal despencou 23\% o Judiciário perdeu somente $6 \%$.

De longe, o dado mais impressionante do gráfico diz respeito ao maior outlier, a Presidência da República. Sua avaliação inicia a série com $66 \%$, rivalizando com a mídia e os militares, e chega em 2015 a 22\%, a segunda mais baixa de todas, perdendo somente para os partidos políticos. A cabeça do Executivo Federal foi a instituição mais afetada em sua popularidade neste período com uma queda de $44 \%$. Se no começo da série não havia um claro padrão de aprovação popular dos poderes, com o Executivo acima do Judiciário e Legislativo, o Governo Federal empatado com o Judiciário e bastante acima do Legislativo, ao final, em 2015, todos os poderes eleitos encontram-se extremamente desvalorizados, enquanto que as instituições que não dependem diretamente do voto popular mantinham entre média e alta taxa de aprovação.

Foquemos agora no penúltimo ano da série, pois ele apresenta comportamento atípico. Como já falamos, é ao longo dele que o Judiciário se descola do Governo Federal em seus índices de aproڤิ vação. Nesse ano, enquanto a i i popularidade das instituições ¿े eleitas cai abruptamente, as ${ }^{35}$ Forças Armadas e a mídia au- 300 ஸิ mentam seu índice de aprova- 250 $\dot{2}$ ção, e o Judiciário permanece 200 లో praticamente constante. Não é 150

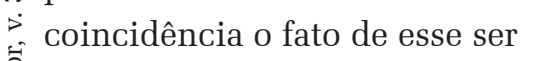
o ano em que começa a Operação Lava Jato.

Vejamos agora como se comportou a mídia. Os gráficos de valência do Manchetômetro acerca do Poder Judici-

Fonte: Manchetômetro, 2019 ário Federal e do Ministério Público Federal, entre janeiro de 2014 e maio de 2018, mostram uma sutileza importante: há um volume expressivo de manchetes, chamadas de primeira página e artigos de opinião de caráter neutro e ambivalente, seguido por material jornalístico de posição positiva e negativa, conforme se pode observar nos Gráficos 2 e 3 a seguir.

Tal tendência também se verifica em relação a outra importante instituição do Sistema de Justiça, o Ministério Público.

Os dois gráficos desvelam uma tendência de discurso neutro da cobertura jornalística quando trata de acusações feitas pelo Ministério Público ou de sentenças proferidas pelo Poder Judiciário, instituições formadas por

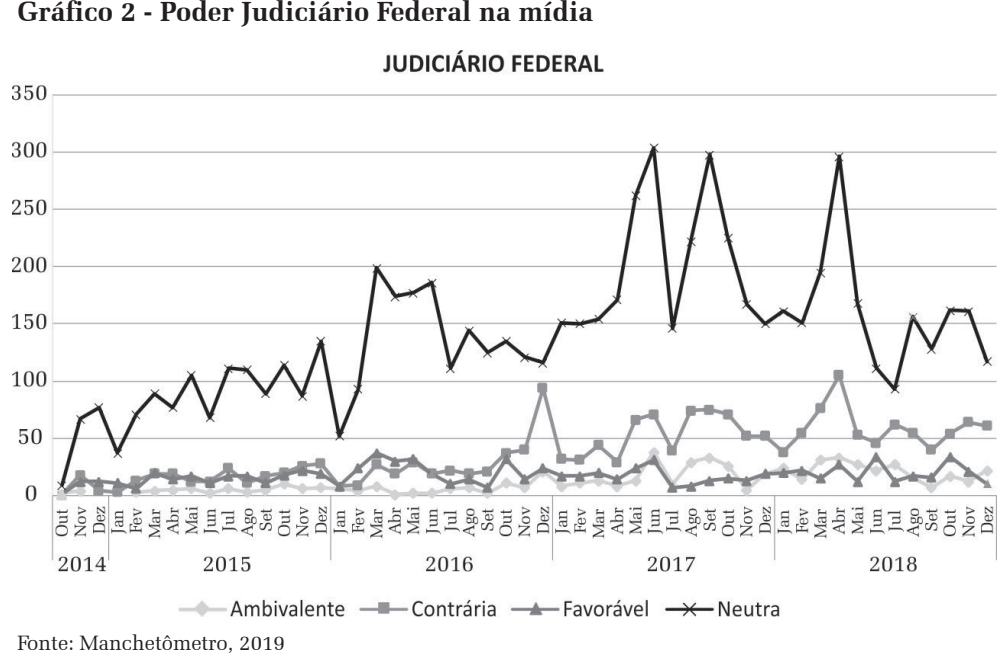

Gráfico 3 - O Ministério Público na mídia

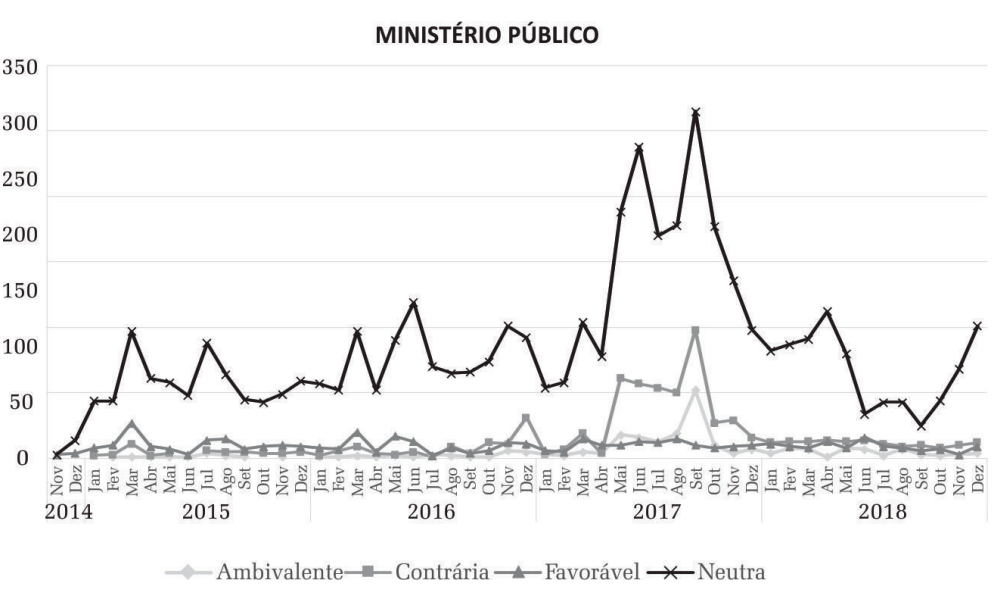


membros não-eleitos pela sociedade. É importante notar que se trata de uma neutralidade expressa acerca de questões altamente controversas, como têm sido muitos atos de juízes e procuradores da Operação Lava Jato. A despeito de qual a posição que tomamos em relação a essa contenda, é inegável que as acusações dos procuradores do Paraná, os vazamentos das escutas feitos por Moro, entre outras muitas ações, são objetos freqüentes de críticas de intelectuais, juristas e políticos. Mas tal contencioso não se reproduz nas páginas de opinião e capas dos grandes jornais, como mostra o gráfico. O que impera nesses espaços noticiosos é uma posição geral de que "ordem judicial não se discute, se cumpre”.

Os picos de presença nos jornais, tanto do Judiciário Federal, como do MPF, estão ligados a momentos cruciais das investigações da Lava Jato: em março de 2015, a Operação comemorava um ano de atividades; já em junho de 2016 havia o debate sobre a possível delação de membros da empreiteira OAS; e finalmente em maio de 2017, maior pico da cobertura neutra, observamos diversos movimentos da Operação como a divulgação de contradição no depoimento do ex-presidente Lula ao então juiz federal Sérgio Moro.

Vejamos agora como se comportou a grande mídia brasileira no mesmo período em relação aos poderes eleitos da república, come-

Gráfico 4- Governo Federal na mídia

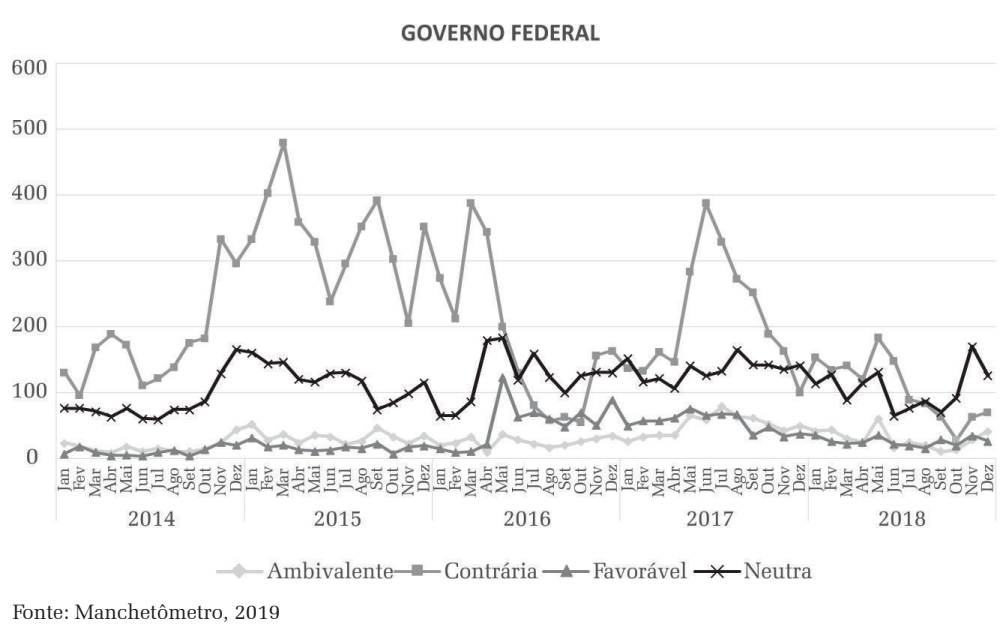

çando pelo Governo Federal.

Temos aqui um padrão bastante diverso daquele mostrado nos gráficos sobre as instituições do Sistema de Justiça. Primeiro porque aqueles revelavam uma tendência consistentemente ascendente, enquanto o perfil da cobertura - observado tanto pelo número absoluto de matérias sobre o tema quanto pela proporção entre as valências favorável, contrária, neutra e ambivalente - se altera significativamente durante o período. Do começo da série até maio de 2016 temos um crescimento consistente do número de matérias, só que, ao contrário das instituições judiciais, no caso do Governo Federal as contrárias dominam com ampla margem. Para se ter uma ideia da diferença, enquanto para aquelas instituições há algo em torno de 10 codificações neutras para uma contrária, para o Governo Federal há, da posse de Dilma até seu afastamento da Presidência, em média duas contrárias para uma neutra.

Em segundo lugar, é importante notar a guinada que a cobertura sofre com a substituição de Dilma Rousseff por Michel Temer, em maio de 2016. O número despenca abruptamente cruzando o de neutras e indo encontrar as favoráveis, que por seu turno sofrem um aumento também abrupto. É a Lua de Mel de Temer, que, como mostra o gráfico, durou muito mais do que os cem dias estimados pela literatura de Ciência Política norte-americana (Johnson, 1983; Hughes, 1995; Li, 1999; Dominguez, 2005)- Dilma, por seu turno, assistiu à intensificação dos ataques ao seu governo já no primeiro mês da segunda gestão. Mesmo com o advento de repetidas denúncias de corrupção contra membros da cúpula do Governo Temer, sua curva de negativas se entremeia à de neutras, em uma cobertura que é duas vezes menos intensa que a de Dilma, como se observa entre outubro de 
2016 e abril de 2017. Sinais mais inequívocos de politização da cobertura da grande mídia são difíceis de se obter.

Agora é a vez do Poder Legislativo, outra instituição da democracia a receber farta cobertura jornalística.

O perfil da cobertura do Legislativo é diverso dos analisados anteriormente. O número de notícias neutras mais ambivalentes é similar ao de contrárias, enquanto que o número de favoráveis é irrisório. Exceção deve ser feita ao período em torno do afastamento da presidente Dilma, quando o número de notícias neutras se descolou, ultrapassando em muito as con-

Gráfico 5- O Legislativo Federal na mídia

LEGISLATIVO FEDERAL

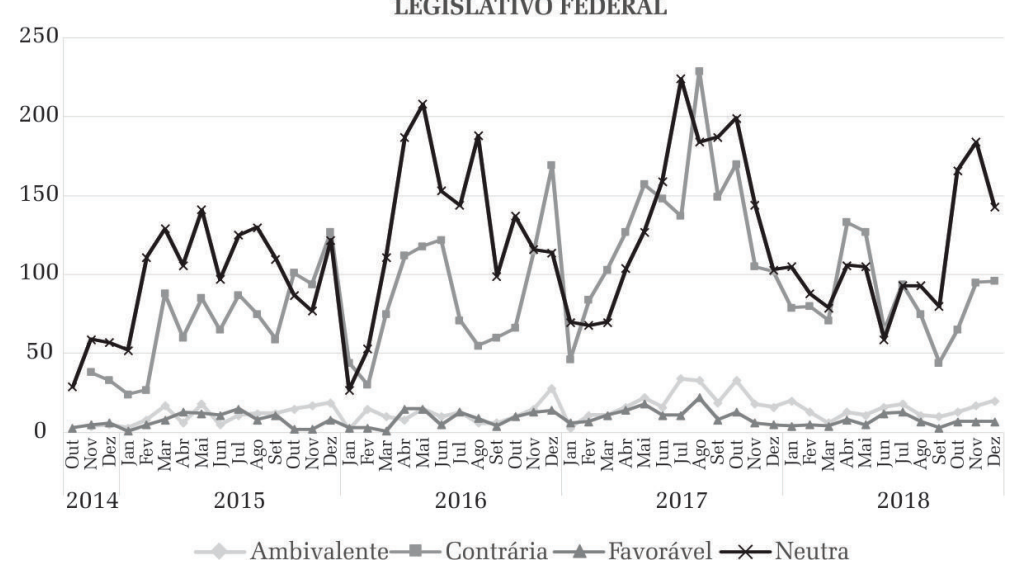

Fonte: Manchetômetro, 2019 começou a série com um patamar baixo de aprovação, obteve uma cobertura negativa, e caiu ainda mais.

Importa repetir aqui que uma cobertura neutra não significa necessariamente neutralidade da imprensa. Dissemos isso já em relação à cobertura das instituições do Sistema de Justiça, mas tal fato torna-se ainda mais óbvio na análise do perfil da cobertura do Governo Federal. Ora, com a ex-presidente Dilma, ela era fortemente negativa. Já o ex-presidente Temer assume a presidência por meio de um processo altamente contestado, com popularidade já de início baixa, em contexto de crise econômica que continua a castigar o Brasil até os dias de hoje, e em meio a uma crise política que só fez piorar durante sua presidência. No entanto, a cobertura do Governo assume perfil de neutralidade durante sua gestão. Assim como tem tratado as contestáveis ações de procuradores e juízes da Lava Jato, a neutralidade em relação ao governo Temer é sinal de politização da mídia, silenciando as vozes críticas, por um lado, e tratando aliados trárias. Ou seja, ao longo do tempo estudado é razoável dizer que, em média, para cada reจิ ferência neutra a essa instituição, há uma desi favorável, o que configura uma cobertura bas¿ tante negativa, mas nem de perto comparada à \& negatividade da cobertura do Governo Federal. $\rightarrow$ de cada uma das instituições ao Gráfico 1 perले cebemos que a que mais despencou, a Presi-

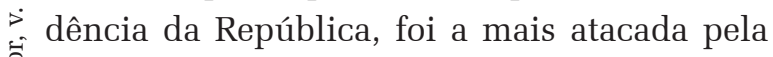
cobertura da imprensa. Também é digno de nota o fato de o Judiciário ter sido o poder de Estado que mais conservou seu relativamente alto nível de aprovação, justamente aquele que obteve a cobertura mais generosamente neutra da grande imprensa. E por fim, o Legislativo senão com elogios claros, como se estivessem fazendo seu devido trabalho.

Durante o período analisado acima, a cobertura midiática esteve claramente centrada na movimentação do judiciário frente os poderes Executivo e Legislativo. É interessante perceber os picos de valência ao longo do período em questão. Em março de 2015, quando a Operação Lava Jato completou um ano, foi divulgada a lista do Procurador-Geral da República, com Rodrigo Janot, enviada ao Supremo Tribunal Federal. Na ocasião, o ministro do STF, Teori Zavascki - morto em janeiro de 2017 em acidente de avião - derrubou o segredo de justiça dos nomes investigados na Lava Jato constantes na lista de Janot. A despeito 
do ato controverso de Zavascki, com claras consequências políticas, a cobertura midiática intensificou enormemente a cobertura negativa do Governo Federal, mas não abriu espaço para críticas ao Ministro.

Em março de 2016, o ex-presidente Lula foi conduzido coercitivamente pela Polícia Federal para prestar depoimento e Janot acusou Dilma Rousseff de obstrução da justiça ao nomear o ex-presidente para o Ministério da Casa Civil. Lula é então impedido de assumir o cargo, com a divulgação pela mídia de grampo telefônico de conversa entre ele e a presidente da República, além de gravações entre a esposa do político, Marisa Letícia, e seus filhos. Em suma, nesse mês assistimos ao pico da cobertura negativa do Governo Federal (e também das coberturas de Dilma, Lula e PT) e também a um pico na cobertura do Judiciário. Contudo, enquanto o pico do Governo é negativo o do Judiciário é neutro, com pouquíssimas matérias negativas no mês. E isso apesar de tanto a condução coercitiva de Lula quanto o vazamento das gravações, ambas ações do juiz Moro, terem sido alvo de intensa contestação por parte de juristas, intelectuais, movimentos sociais e forças políticas de esquerda. Ou seja, a mídia escolheu não publicar a controvérsia, apoiando assim as ações do juiz federal.

Em maio, outro pico de cobertura aconteceu quando o ex-procurador Janot ofereceu denúncia contra Lula. Nesse mesmo mês, o então presidente da Câmara Eduardo Cunha foi afastado pelo ministro do STF Teori Zavascki, e o ex-ministro José Dirceu foi condenado a 23 anos de prisão pelo juiz Sérgio Moro. Em julho do mesmo ano, com Dilma já afastada da presidência até a decisão final do impeachment pelo Senado Federal, Cunha foi acusado de receber propina e o empresário Marcelo Odebrecht foi condenado a 15 anos de prisão. Em dezembro do mesmo ano, Lula se tornou réu pela quinta vez. O então presidente do Senado Renan Calheiros foi afastado do cargo, mas ignorou a decisão do STF e continuou no Senado. Depois, o Supremo vota o seu afastamento e decide por sua permanência no cargo. Enquanto a cobertura neutra do Judiciário continuou aumentando sua ativação, o Governo Federal passou, agora sob Temer, a ser objeto de cobertura benevolente da mídia, como já mostramos.

\section{CONCLUSÃO}

O presente artigo explora a hipótese de que houve posicionamento militante da grande imprensa em favor do Sistema de Justiça em detrimento da imagem do Executivo Federal durante o segundo mandato de Dilma Rousseff. É fato plenamente observável, como mostramos, que há uma correlação entre a cobertura negativa do Governo Federal e a queda da sua avaliação durante o período estudado, que foi bastante abrupta. Se a cobertura midiática foi causa necessária de tal queda, essa é uma questão mais complexa, a qual esse ensaio não responde totalmente, apesar de apresentar alguns indícios forte de que tenha sido. Vários argumentos corroboram tal interpretação. Vamos a eles.

Como já dissemos acima, as grandes empresas detêm praticamente o monopólio da produção de conteúdo jornalístico em nosso país (Feres Jr et al., 2015). Por outro lado, o cidadão comum tem em geral pouco contato com instituições como Presidência da República, Poder Judiciário, Ministério Público etc. Mesmo seu contato com políticas públicas federais é geralmente mediado por parceiros estaduais e municipais, como é o caso dos serviços públicos de saúde e educação. Em outras palavras, a cognição das coisas políticas é quase sempre mediada. Não bastasse isso, estudos de recepção de notícias mostram que quanto menor o contato direto de uma pessoa com um determinado assunto, menor sua capacidade de resistir aos enquadramentos recebidos pela mídia (Jauss, 1982; Lewis, 1995).

A grande mídia frequentemente define seu papel no regime democrático como o de manter o poder sob constante escrutínio. 
Esse é a conhecida função de Watchdog, ou de Quarto Poder (Marcondes Filho, 2002; Mesquita, 2003). Não bastasse isso, no Brasil há praticamente uma unidade de sentido acerca das instituições brasileiras em veículos distintos de comunicação. Em outras palavras, esse consenso aparece como verdade única aos olhos do consumidor de notícias incauto. Contudo, dados como a reversão de curvas e esfriamento da cobertura do Governo Federal, logo em seguida ao afastamento de Dilma, e o padrão benevolente da cobertura dedicada a Temer, assim que assumiu a presidência, refutam a auto imagem da grande imprensa. Este político pemedebista e seu governo, não teria razões objetivas para merecer tal cobertura se a mídia brasileira fosse de fato vigilante do interesse público. E, ainda que num segundo momento o padrão de notícias tenha adquirido um perfil mais negativo (em especial na cobertura dos meios do Grupo Globo), após as denúncias feitas pelo empresário Joesley Batista, com gravações telefônicas indicando prática de corrupção passiva pelo peemedebista, tal negatividade não se compara em intensidade àquela devotada à Dilma Rousseff, mesmo que sobre a ex-presidente não houvesse imputações concretas de envolvimento em ações ilícitas.

Por fim, podemos formular a objeção de que as ações dos poderes que compõem o Sistema de Justiça são técnicas e, portanto, politicamente neutras, daí ser natural a granจิ de mídia lhes dedicar uma cobertura neutra. กิ Contudo, isso não é verdade, pois tais ações ¿े são contestadas por muitos juristas ilustres ชे (Cittadino, 2004; Proner et al., 2016), por inteจิ lectuais e também por políticos e movimentos $\dot{\sim}$ sociais. Uma mídia verdadeiramente vigilante ळ deveria noticiar o dissenso em torno de tais

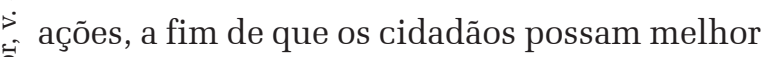
formar sua opinião acerca dos acontecimentos em nosso país.

Voltemos agora para a questão mais de fundo do nosso artigo, que é a da judicialização da megapolítica. É indubitável que a atual crise política brasileira se dá, senão por causa, pelo menos em meio a um surto desse fenômeno. É também incontestável o papel que a grande mídia teve, como mostramos, na corrosão da legitimidade dos poderes eleitos, e na proteção, senão promoção, dos poderes do Sistema de Justiça - Judiciário e Ministério Público. A relação entre mídia e instituições da justiça é, contudo, bastante assimétrica. A imprensa tem enorme poder em prover e retirar legitimidade das instituições, mas não tem poder de enforcement de suas decisões, isto é, a mídia não pode diretamente impor seus desígnios sobre os cidadãos. Já as instituições da justiça dependem fortemente da legitimidade que a mídia lhes provê para subjugar os poderes eleitos, e assim enforce suas decisões sobre os cidadãos.

Nessa associação com o Sistema de Justiça, a mídia ganha poder e autonomia frente aos políticos eleitos: o PT foi finalmente derrotado após seguidas vitórias eleitorais, sua presidente da República impedida, e o novo governo imediatamente começou a implementar políticas de corte neoliberal inteiramente em consonância com a posição da grande imprensa. O Sistema de Justiça, por seu turno, segue cada vez mais empoderado numa campanha contra a corrupção que está varrendo o sistema político e empresarial brasileiro, se jactando em campeão da república ao passo que deixa no seu rastro um amontoado de escombros.

O exemplo brasileiro da atualidade mostra que a teoria da judicialização da megapolítica de Hirschl é um bom começo, mas precisa de complementação e revisão. Se de fato o fenômeno é de natureza política e se a legitimidade é um bem fundamental na política, então é preciso entender melhor como essa legitimidade é produzida e transacionada no jogo entre os poderes. Em sociedades contemporâneas de massa, é impossível pensar tal produção de legitimidade sem levar em conta o contexto comunicacional, como mostramos aqui.

Se a judicialização da megapolítica é ruim para a saúde da democracia, e tudo indica que é esse o sentido normativo com o qual Hirschl sutilmente impregna seu texto, porque re- 
presenta distúrbio funcional, a mídia que posa de Watchdog (cão de guarda) mas age de modo fortemente politizado, é também uma distorção séria. Não é o caso de pretender que ambas as instituições fiquem imunes a influências políticas, o que seria um idealismo ingênuo. Contudo, também não é solução adotarmos uma postura cínica e concluir que sua forte politização deve ser algo natural e tolerável. Mídia e instituições do Sistema de Justiça têm papeis importantes no desenho da democracia representativa, e seu mal funcionamento traz sérios problemas para o conjunto, ainda mais quando ele se dá de maneira combinada, como vimos aqui: a mídia capturada por interesses políticos e concentrada em uma estreita faixa do espectro ideológico enquanto que as instituições do Sistema de Justiça exorbitam suas prerrogativas ameaçando a soberania do voto popular. ${ }^{11}$

Frente à corrosão da imagem da política institucional, de partidos, dos políticos e do Congresso, há aqueles que sonham com uma república governada por juízes e procuradores de justiça. Se há ainda uma franja ultraconservadora da população brasileira que sonha com o retorno dos militares, os heróis dos autoritários de antanho, os salvadores da pátria de boa parte da classe média e média alta que foi às ruas em junho de 2013, e depois voltou com força nos anos seguintes para pedir o impeachment de Dilma, são os jovens burocratas do Sistema de Justiça, com seus terninhos engomados e ares de bom-mocismo. Da antiguidade clássica aos dias de hoje há quem defenda que a melhor forma de governo é a dos mais "virtuosos", daqueles de "reputação ilibada", dos "homens de bem”. Não nos esqueçamos, porém, que o nome de tal regime não é democracia.

Recebido para publicação em 20 de setembro de 2017 Aceito em 29 de junho de 2020

${ }^{11}$ É importante anotar (1) que o Brasil não é o único país a sofrer desses males e (2) que a judicialização da megapolítica frequentemente conta, para além da aliança entre Sistema de Justiça e grande mídia, com a colaboração de políticos de oposição, conforme descreveu o defensor de direitos Humanos Adolfo Perez Esquivel (2016). O mesmo cenário se repetiu em vários países da América Latina, com as quedas dos presidentes de Honduras e Paraguai (Fernandes, 2017).

\section{REFERÊNCIAS}

ALBUQUERQUE, Grazielle. Mídia e Justiça no Brasil: o Mapeamento das pautas históricas de uma nova relação. Mediapolis-Revista de Comunicação, Jornalismo e Espaço Público, n. 5, p. 51-73, 2017.

ALBUQUERQUE, Afonso. A Comunicação Política depois do Golpe: notas para uma agenda de pesquisa. Revista Compolitica, v. 8, p. 171-206, 2018.

ALDÉ, Alessandra. As eleições presidenciais de 2002 nos jornais. ALCEU v. 3, n. 6, p. 93-121, 2003.

ALDÉ, A.; MENDES, G.; FIGUEIREDO, M. Imprensa e eleições presidenciais: Natureza e Consequências da cobertura das eleições de 2002 e 2006. In: LIMA, V. A. D. (Ed.). A mídia nas eleições de 2006. São Paulo: Editora Perseu Abramo, 2007.

ARANTES, R. R. B. Judiciário \& política no Brasil. São Paulo, SP: EDUC: FAPESP : IDESP, Editora Sumaré, 1997. 215 p. ISBN 8585408219.

AVRITZER, L.; MARONA, M. C. Judicialização da política no Brasil: ver além do constitucionalismo liberal para ver melhor. Revista Brasileira de Ciência Política, n. 15 , Brasília, p. 69-94, 2014.

BECKER, Camila et al. Manifestações e votos sobre impeachment de Dilma Rousseff na primeira página de jornais brasileiros. Revista Latinoamericana de Ciencias de la Comunicación, v. 13, n. 24, 2017.

BIROLI, Flávia; MIGUEL, Luis Felipe. Notícias em disputa: mídia, democracia e formação de preferências no Brasil. 1. ed. São Paulo: Contexto, 2017. v. 1. 224p

BORBA, F. D. M.; VEIGA, L. F.; MARTINS, F. B. Propaganda negativa na campanha presidencial em 2014: Ou como tudo que é frágil se desmancha no ar. Revista Estudos Políticos v. 6, n. 1, p. 182-200, 2015.

BORK, R. H. Coercing virtue: the worldwide rule of judges / Robert H. Bork. Toronto: Vintage Canada, 2002. ISBN 0679310932.

BRASIL. Constituição da República Federativa do Brasil. Brasília: Senado Federal: Centro Gráfico: 292 p. 1988.

BRITTOS, V. R. C.; BOLAÑO, C. S. Rede Globo: 40 anos de poder e hegemonia. 2a. São Paulo, Brasil: Paulus, 2005. 373 p. ISBN $853492337 \mathrm{X}$.

CARVALHO, E. Judicialização da política no Brasil: controlo de constitucionalidade e racionalidade política. Análise Social, v. XLIV, n. 191, p. 315-335, 2009.

CITTADINO, G. Poder Judiciário, ativismo judiciário e democracia. Revista Alceu, v. 5, n. 9, p. 9, 2004.

COLLING, L. Os estudos sobre o Jornal Nacional nas eleições pós-ditadura e algumas reflexões sobre o papel desempenhado em 2002. In: RUBIM, A.; CANELAS, A. (Ed.). Eleições presidenciais em 2002: ensaios sobre mídia, cultura e política. São Paulo: Hacker Editores, 2004. p.53-67.

DELLA VIGNA, Stefano; ETHAN, Kaplan. The Fox News Effect: Media Biasand Voting. Quarterly Journal of Economics, v. 122, 2007.

DOMINGUEZ, C. B. K. Is It a Honeymoon? An Empirical Investigation of the President's First Hundred Days. Congress \& the Presidency, v. 32, n. 1, p. 63-78, 2005/03/01, 2005.

DOWNING, J. Midia Radical. São Paulo: SENAC, 2002.

ENTMAN, R. M. Framing: Toward Clarification of a Fractured Paradigm. Journal of Communication, v. 43, n. 4, p. 51-58, 1993.

EPP, C. The Rights Revolution: Lawyers, Activists and Supreme Courts in Comparative Perspective. Chicago: Chicago University, 1998. 
ESQUIVEL, A. P. Golpe no Brasil é parte de um projeto de recolonização da América Latina. Sul21, n. 2 maio, 2016.

FERES JÚNIOR, J. et al. Testando a hipótese do contrapoder: A cobertura das eleições de 1998 e 2014. VI Congresso Compolítica. PUC-Rio: 23 p. 2015.

FERES JÚNIOR, J. Em defesa das valências. Revista Brasileira de Ciência Política, nº19. Brasília, p. 277-298, 2016.

FERNANDES, P. A Judicialização da Megapolítica no Brasil: O Protagonismo do STF no Impeachment de Dilma Rousseff. 2017. (Mestrado em Direito). PUC-RIO, Rio de Janeiro.

GENTZKOW, M. Television and Voter Turnout. Quarterly Journal of Economics, v. CXXI n. 3, 2006.

GIBSON, J. L.; CALDEIRA, G. A.; SPENCE, L. K. The Supreme Court and the US Presidential Election of 2000: Wounds, Self-Inflicted or Otherwise? British Journal of Political Science, v. 33, n. 4, p. 535-556, 2003. ISSN 00071234, 14692112. Disponível em: < http://www.jstor. org/stable/4092195>.

GILLMAN, H. How Political Parties Can Use the Courts to Advance Their Agendas: Federal Courts in the United States, 1875-1891. The American Political Science Review, v. 96, n. 3, p. 511-524, 2002.

GINSBURG, T. Judicial Review in New Democracies: Constitutional Courts in Asian Cases. Cambridge University Press, 2003.

GRABER, M. From the Countermajoritarian Difficulty to Juristocracy and the Political Construction of Judicial Power. Maryland Law Review, v. 65, n. 1, p. 14, 2006.

HABERMAS, J. On the logic of the social sciences. Cambridge: MIT Press, 1988.

HIRSCHL, R. The Political Origins of the New Constitutionalism. Indiana Journal of Global Legal Studies, v. 11, n. 1, p. 39, 2004.

HIRSCHL, R. The Judicialization of Mega-Politics and the Rise of Political Courts. Annual Review of Political Science, v. 11, n. 1, p. 93-118, 2008.

HOPKINS, D. J.; KING, G. A Method of Automated Nonparametric Content Analysis for Social Science. American Journal of Political Science, v. 54, n. 1, p. 229247,2010 .

HUGHES, W. J. The "Not-So-Genial” Conspiracy: The New York Times and Six Presidential "Honeymoons," 19531993. Journalism \& Mass Communication Quarterly, v. 72, n. 4, p. 841-850, December 1, 19951995.

i JAUSS, H. R. Toward an aesthetic of reception. Minneapolis: จ University of Minnesota Press, 1982. xxix, 231 p. ISBN is 08166103470816610371 (pbk.).

JOHNSON, K. S. The Honeymoon Period: Fact or Fiction? ชิ Journalism Quarterly, v. 60, n. 3, p. 869-876, 1983.

KELEMEN, R. D.; SIBBITT, E. C. The Globalization of ㄱ American Law. International Organization, v. 58, n. 1, p.

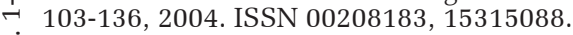

$\dot{2}$

KERCHE, F. B. Virtude e limites: autonomia e atribuiç̃es ๓ do Ministério Público no Brasil. São Paulo, SP, Brasil: $>$ EDUSP, 2009. 118 p. ISBN 9788531411946.

KING, G.; PAN, J.; ROBERTS, M. E. How Censorship in China Allows Government Criticism but Silences TI Collective Expression. American Political Science Review, v. 107, n. 2, p. 1-18, 2013.

KRAMER, L. The People Themselves: Popular Constitutionalism and Judicial Review. New York: Oxford University Press, 2004. ISBN 9780195306453.

LEWIS, S. Reading images: narrative discourse and reception in the thirteenth-century illuminated apocalypse. Cambridge; New York: Cambridge University Press, 1995.

LI, Y. Setting the Media Agenda: The President and His Honeymoon with the Media. Association for Education in Journalism and Mass Communication Annual Convention. New Orleans 1999.

LIMA, V. A. D. Mídia: teoria e política. 1a. São Paulo, SP, Brasil: Editora Fundação Perseu Abramo, 2001. 365 p. ISBN 8586469602

LIMA, V. A. D.; ALDÉ, A. A mídia nas eleições de 2006. 1a. São Paulo, SP, Brasil: Editora Fundação Perseu Abramo, 2007. 284 p. ISBN 9788576430568.

LOVELL, G. Legislative Deferrals: Statutory Ambiguity, Judicial Power, and American Democracy. New York: Cambridge University Press, 2003.

LUHMANN, N. Social systems. Stanford: Stanford University Press, 1995.

LYCARIÃO, D.; CARVALHO, E. M.; ALBUQUERQUE, A. de. Noticiário objetivo em liquidação: a decadência do padrão catch-all na mídia comercial. Revista Famecos (Online), v. 25, p. 1-19, 2018.

MAIA, R.C.M. Deliberation, the media and political talk. New York, NY: Hampton Press, 2012.

MARCONDES FILHO, C. Comunicação e Jornalismo: A Saga dos Cães Perdidos. São Paulo: Hacker Editores, 2002.

MCCOMBS, M. E. A look at Agenda-setting: past, present and future. Journalism Studies, v. 6, n. 4, p. 14, 2005.

MCCOMBS, M. E. A Teoria da Agenda: a mídia e a opinião pública. Petrópolis: Vozes, 2009.

MCCOMBS, M. E.; SHAW, D. L. A função do agendamento dos media. In: TRAQUINA, N. (Ed.). O poder do jornalismo: análises e textos da Teoria do Agendamento. Coimbra: Minerva, 2000. p. 47-61.

MESQUITA, M. O Quarto Equívoco: o poder dos media na sociedade contemporânea. Coimbra: Minerva Coimbra, 2003.

MIGUEL, L. F. Mídia e manipulação política no Brasil: a Rede Globo e as eleições presidenciais de 1989 a 1998. Comunicação \& Política, v. VI, n. 2-3, p. 119-138, 1999.

MORO, S. F. Considerações sobre a operação mani pulite. Revista Jurídica Centro de Estudos Judiciários, v. 8, n. 26, p. 56-62, 2004.

MUNDIM, P. S. Imprensa e voto nas eleições presidenciais brasileiras de 2002 e 2006. Revista de Sociologia e Política, v. 20, p. 123-147, 2012.

MUNDIM, P. S. Cobertura da imprensa e eleições presidenciais de 2006 efeitos realmente limitados? Revista Brasileira de Ciências Sociais, v. 29, p. 91-107, 2014.

PRONER, C. E. A. et al. A resistência ao golpe de 2016. Bauru: Praxis Editora, 2016. 432 p.

RIZZOTTO, C.; PRUDENCIO, K.; SAMPAIO, R. C. TUDO NORMAL: a despolitização no enquadramento multimodal da cobertura do impeachment de Dilma Rousseff. Comunicação \& Sociedade, v. 39, n. 3, p. 111130, 2017.

SANTOS JR, M. A.; ALBUQUERQUE, A. Perda da hegemonia da imprensa: a disputa pela visibilidade na eleição de 2018. Lumina. Juiz de Fora, PPGCOM - UFJF, v. 13, n. 3, p. 5-28, set./dez. 2019.

SCHEINGOLD, S. The Politics of Rights: Lawyers, Public Policy, and Political Change. New Haven: Yale University Press, 1974.

SHAPIRO, M. The success of judicial review. In Constitutional Dialogues in Comparative Perspective. 
New York: Palgrave Macmillan, 1999.

SODRÉ, N. História da imprensa no Brasil. Rio de Janeiro: Mauad, 1999.

STONE-SWEET, A. Governing with Judges: Constitutional Politics in Europe. Oxford: Oxford University Press, 2000.

TATE, Neal Tate; VALLINDER, Torbjörn. The Global Expansion of Judicial Power, New York: New York University Press, 1991.

TEUBNER, G. Juridification of the Social Spheres. New York: Walter de Gruyter, 1987.

TUSHNET, M. Taking the Constitution Away from the Courts. Princeton: Princeton University Press, 1999.
VOGEL, S. Freer Markets, More Rules. Ithaca: Cornell University Press, 1998.

WALDRON, J. The Core of the Case Against Judicial Review. The Yale Law Journal, n. 115, p. 15, 2006.

WERNECK VIANNA, L. A Judicialização da Política e das Relações Sociais no Brasil. Rio de Janeiro: Revan, 1999.

WHITTINGTON, K. Political Foundations of Judicial Supremacy: The Presidency, the Supreme Court, and Constitutional Leadership in U.S. History. Princeton:

Princeton University Press, 2007. 
THE JUDICIALIZATION WAS BROADCAST: the relationship between the media and the system of justice in Brazil

\author{
João Feres Júnior \\ Patricia Bandeira de Melo \\ Eduardo Barbabela
}

What is the role of the Justice System in the current process of institutional conflict in Brazil? Through a critical analysis of the concept of the judicialization of megapolitics, proposed by Ran Hirschl, we discuss the role of the Judiciary and Public Prosecutor's Office in the current Brazilian political crisis. We call attention to the lack of clarity in Hirschl's analysis about the fundamental problem of legitimacy in the conflict between governmental branches, and then we show how there is strong evidence in the Brazilian case that the mainstream media had the function of shifting legitimacy from the elected powers to the institutions of the System of Justice. To test our hypothesis, we compare the evolution of the popular approval of the main institutions of Brazilian democracy with the coverage that the quality newspapers Folha de S. Paulo, Estado de S. Paulo and Globo, and the television news program Jornal Nacional have dedicated to them from the beginning of 2014 until now, using data from the Manchetometro project. We conclude by suggesting improvements to the study of judicialization and particularly to the concept of the judicialization of the megapolitics.

Keywords: Judicialization of politics. System of justice. Media. Public opinion. Attorney general
LA JUDICIALISATION A ÉTÉ DIFFUSÉE: la relation entre les médias et le système de justice

\author{
João Feres Júnior \\ Patricia Bandeira de Melo \\ Eduardo Barbabela
}

Dans quelle mesure le système de justice joue-t-il un rôle de premier plan dans le processus actuel de conflit institutionnel au Brésil? À partir d'une analyse critique du concept de Judicialisation Megapolitique, proposée par Ran Hirschl, nous avons discuté du rôle du pouvoir judiciaire et du ministère public dans la crise politique brésilienne actuelle. Nous attirons l'attention sur le manque de clarté dans l'analyse de Hirschl sur le problème fondamental de la légitimité dans le conflit entre les pouvoirs, puis nous montrons comment il existe de fortes preuves dans l'affaire brésilienne selon laquelle les médias traditionnels ont pour fonction de transformer la légitimité des pouvoirs élus en institutions des Système de justice. Afin de prouver notre hypothèse, nous comparons l'évolution de l'approbation populaire des principales institutions de la démocratie brésilienne avec la couverture que les journaux Folha de S. Paulo, État de S. Paulo et Globo et le journal Jornal Nacional leur ont consacré dès le début de 2014 jusqu'à présent, en utilisant les données d'enquête du Manchetomètre. Nous concluons en suggérant quelques améliorations à l'étude de la judiciarisation et en particulier à la notion de judiciatisation de la mégapolitique.

Mots-CLÉs: Judicialisation de la politique. Système de justice. Médias. Opinion publique. Analyse d'évaluation

João Feres Júnior - Doutor em Ciência Política pela City University of New York. Professor associado do IESP-UERJ. Coordena o Observatório do Legislativo Brasileiro (OLB), o Grupo de Estudos Multidisciplinares da Ação Afirmativa (GEMAA), dedicado ao estudo das desigualdades racial e de gênero, e o Laboratório de Estudos da Mídia e Esfera Pública (LEMEP), que abriga os sites Manchetômetro (http://www.manchetometro.com.br). Autor de vários livros, estudos e artigos científicos sobre teoria política, mídia e política, políticas de ação afirmativa, relações raciais, desenvolvimento institucional das ciências sociais, história conceitual e estudos da América Latina.

Patricia Bandeira de Melo - Doutora em Sociologia. Pesquisadora titular. Professora do Mestrado em Ciências Sociais para o Ensino Médio da Fundação Joaquim Nabuco (MPCS/Fundaj). Membro do Núcleo de Estudos em Estatísticas Sociais da Fundaj (NEES/Fundaj) e pesquisadora associada do LEMEP. Tem interesse em estudos de mídia, discurso, consumo e métodos de análise qualitativa. Autora do livro $O$ Financiamento do Cinema: os níveis de intervenção estatal na produção mundial (Recife: Massangana, 2014); Histórias que a mídia conta: o discurso sobre o crime violento e o trauma cultural do medo (Recife: Editora Universitária, 2010).

Eduardo Barbabela - Doutorando em Ciência Política no IESP-UERJ. Bacharel em Ciência Política pela Universidade Federal do Estado do Rio de Janeiro. Pesquisador do LEMEP. Tem experiência na área de ciência política, com ênfase em teoria política, estudos eleitorais, mídia e política, favela e representação urbana. 